\title{
Eastern forms in Yakut poetry: transformation features (the works of A. Parnikova-Sabara-llge as a case-study)
}

\author{
Matrena Popova* \\ North-Eastern Federal University named after M.K. Ammosov, 677000, 58 Belinsky str., Yakutsk (Republic of Sakha), \\ Russian Federation
}

\begin{abstract}
This article attempts to comprehend the innovations of Yakut poets in the creation of small-form genres in modern Yakut poetry, namely forms borrowed from the Eastern poetry, to be more exact, the poetry created by Anna Parnikova-Sabaray-Ilge as a case-study. The tendency of the poetess in her poetic stylization of the Eastern genres is to enrich the modern genre systematizing the examples from the treasury of world literature. As early as the 1960s and 1970s, Yakut poets sought to master oriental forms. However, in their poems they did not strictly follow the requirements of certain oriental forms. Only in the early 2000s young poet A. Parnikova managed to keep to the special requirements of the hard forms, namely the eastern ghazals. Although the author managed to nationalize the imagery, for example, the author used lilies instead of tulips, we consider her poem a model of oriental forms in the Yakut style.
\end{abstract}

\section{Introduction}

Over the last three decades, we have celebrated the enrichment of Yakut poetry in terms of the search for genres. Poets frequently turn to folklore forms and techniques. Literary translations made by Yakut poets as early as the 1960 s and 1970 s contributed to the appearance of such firm European genre forms as sonnets, a crown of sonnets and ballads in modern Yakut poetry. Additionally, in the genre system of individual Yakut poets there are experiments in which oriental classical forms are created; their examples include such poetic forms as ghazals, tankas, rubais, etc.

In this article, due to the large scale of the problem, we do not intend to cover all genre forms of modern Yakut poetry. We limited ourselves to considering small forms with tendencies towards innovativeness as it is more significant in modern Yakut poetry and the history of Yakut literature in general. Forms borrowed from world literature have come to the center of attention.

\section{Materials and Methods}

Yakut poets turned to genre forms of Eastern poetry later - in the 1970s, but, as Yakut scholars noted, these samples were not exact copies of rubai and hokku, but were more like proverbs and sayings, however, they were much deeper in their meaning [1].

Yakut poets of the 1970s did not particularly follow the strophic and poetic features of any Eastern genre. Their works are figurative, often philosophical reflections put into the quadruple or pentameter poetic form. However, in modern Yakut poetry, the poets continue to appeal to verse forms of lyrical poetry of other peoples, which together made up the culture of the East. For example, Japanese tankas, haiku, native Arabic-language, Persian-language, Turkic-language poetry, and poetic forms such as rubai, ghazals, which are part of the arsenal of genres of modern Yakut poetry and, in our opinion, they have come much closer to original poetic forms in terms of imagery and composition.

For example, in the tanka by N. GerasimovAytalyn (a series of tanka poems titled "Hyharangnga" - "In Silence"), I. Bayeshev (a cycle of tanka poems titled "Kihibuoluutordo" - "Origins of becoming a man"), which consists of reflections on such eternal topics as moral appearance of a modern person, friendship, loneliness, and love.

Table 1. The tanka by Aitalyn.

\begin{tabular}{|l|l|}
\hline English translation & Yakut (transliteration) \\
\hline $\begin{array}{l}\text { Where I have confessed } \\
\text { my love }\end{array}$ & $\begin{array}{l}\text { Taptyyrbyn eppit } \\
\text { Tatiyiktaah kyrdalbar } \\
\text { On the high meadow } \\
\text { where the birds sing } \\
\text { Light-wing spring hasellesaas. } \\
\text { Bihigini utukter } \\
\text { come. }\end{array}$ \\
$\begin{array}{l}\text { One are imitated } \\
\text { By the youth which eder saas. } \\
\text { grows there }\end{array}$ & \\
\hline
\end{tabular}

\footnotetext{
*Corresponding author: pmatrena75@mail.ru
} 
The authors strictly adhere not only to the national form of the five-line poem of Japanese poetry, where the number of syllables in one tanka is equal to 31 , but also to the experience in the spirit of the Eastern contemplation: a thoughtful and balanced harmony. There is a sense of measure, refined elegance, smooth lines and a soft range of colours, semitones and shades. We shall bring the tanka by Aitalyn as an example.

In this tanka, the first and third lines consist of five syllables, others being the second, fourth, and fifth of the seven syllables in total. This is the syllabic combination of all the other tanka poems created by the poet and his works under discussion. The emotions and thoughts of the poet are transmitted in the spirit of Eastern contemplation: elusive strokes, vague shapes of images, forming the basic idea characteristic features of the tankas created by poet N. Gerasimov-Aytalyn.

Compared to other Eastern genres, ghazals in Yakut poetry appeared only in the modern timeperiod and they are perceived not only as an experience of poetic stylization, but also as an attempt to recreate a structural-meaningful and compositional-strophic feature of this genre.

\section{Results and Discussion}

In Russian literature, the genre of ghazals has been studied by such famous orientalists as I.V. Stebleva, S.N. Ivanov, E.E. Bertels. In their works, they focus on the history of the formation and development of the ghazals as a genre in Turkic literature (S. Ivanov), as well as its structural, semantic, compositional (I. Stalev) and figurative (E. Bertels) features.

Transferred from Arabic classical literature to the platform of Persian literature, ghazals became its main lyrical genre, and in this form they entered into the classical Turkic poetry at the end of the 14th century. Ghazals were written by Central Asian poets such as Lutfi, Navoi, Babur and others.

In Persian treatises, devoted to the theory of poetic art, there is a thorough description and large scope of data on the requirements of meaning imposed on ghazals and the characteristics of its main formation elements. The ghazals are fully described in the works of Shamsadin Muhammad b. Kaisa alRazi in the "Alphabetic List of Rules of Persian Poetry" as well as by Kabul Muhammad in his "Khaft kulzum"("Seven Seas") in which he tells “...a story about women and a description of love grooming for them... And since the goal of the ghazals is to calm the mind and appease the soul, it is necessary that its construction is good-sounding and fits the poetic size. And in the case of words, it should be pleasant and expressive and has (in itself) a clear meaning. As for the verse, it is necessary to be aware of inappropriate expressions and coarse words" [2]. Ghazals are also interpreted as follows: “...in the terminological meaning it is a few baits united by the poetic size and rhyme. And the first of these baits is the matla and the matla is called the bait, both misras of which rhyme. ...The last bait is called the maqta or khatima. It is necessary that (in ghazals) there should be no more than eleven or twelve baits. Some consider the limit (for) ghazals to be nineteen baits" [2]. Thus, the rules of writing ghazals, established in the 8th century, have become a norm of creating a fictional text within this genre.

For a long time, there was a belief that there was no connection between the baits of ghazals. Researcher I. Steblev rejects this judgment and in the example of the ghazals created by poet Babur, the scholar proves the contrary. "...the linear sequence in which the meaningful material is structured in the ghazals created by Babur is logically predetermined by the course of the author's thought, which is aimed at creating a further flow of meaning, and achieve its development. It is the need to develop the meaningful content of ghazals that requires "... elements of the composition, which are semantically interdependent in ghazals composed by Babur. And they have a fixed position, and this, in turn, completely excludes the possibility of changing the position of the baits without losing the sense and artistic expression of the texts" [2].

In the anthology of Yakut poetry titled "Poets of the twentieth century" (2000), there were 5 ghazals created by young poetess A. Parnikova-Sabaray Ilge.

Since the genre of ghazals aspires to reflect the state of love of lyrical character from the first-person point of view, towards the beautiful woman, the beloved one, there are two characters in it: the lyrical hero and the object of love - a woman. In the ghazals by Anna Parnikova-Sabaray Ilge, there are also two semantic centers: the lyrical hero or "I" and an object of admiration. Only the lyrical subject of the ghazal is a woman, the lyrical heroine, and the object of the ghazal is a man. Such substitution of roles in ghazals existed already in the 15 th century when Turkic female poets first appeared. For example, Turkish poet Mihri-khatun (1456-1512 circa), Azerbaijani poet Natavan (1830-1897) and others were known for their talented poems [3].

Ghazals by A. Parnikova are written in a dialogue form. The addressees of the lyrical heroine are the man and his idealized and generalized image, which has the power "to give" her paradise and an out-ofthis-world life.

According to our observation, while in the ghazals of Eastern poets, the lyrical hero suffers from a cold attitude towards him on behalf of the lover, in ghazals of the Eastern female poets, the lyrical heroine suffers the most from the infidelity of the lover. Thus, in Ancient Turkic ghazals lyrical heroes are presented as suffering, poor people (the description of appearance also coincides with this condition), while the lyrical heroine of the Yakut poetess differs from them with a more "soft attitude" towards oneself. Therefore, she has a tender and loving heart. She also confesses to her unbridled nature, to her inability to free herself from the 
ordinary state and to comprehend life, thus, living the dream.

The imagery system of ghazals as a genre is thoroughly studied and presented in historical documents. In her ghazals, the Yakut poetess adheres to constructive principles of adding up to the image of a system of ancient Turkic poets. But the building material that makes up the A. Parnikova-Sabarai Ilge ghazal system is the native nature, as well as the material and spiritual culture of the Sakha people. Regarding the author's innovations in the genre of ghazal, S.N. Ivanov writes, “...the art of ghazals and the creativity of the author depended on how uniquely he managed to "transform" the familiar image. The elements of combinations are strictly set, (of course, in a range that allows implementing the widely known variation); the combination must be special and unique..." [4].

Similar to the ghazals of ancient Turkic poets, the images used in the ghazals of the Yakut poetess are related to the main characters: the female and male characters in love. I. Stebleva points out that in the Ancient Turkic ghazals, "in one of the cases of occurrence, the created image must show that the female lover is beautiful because she is charming, she is graceful, seductive, etc. for different reasons and sometimes for the same reasons. The depicted poetic character also has many facets of the image: he is longing for love, suffering, crying, dreaming, hopeful, thirsty, etc." [5].

We analyze the objects and concepts with which A. Parnikova compares parts of the face of the male lover, i.e.: "cheeks are like the shining sky, eyes are like shining rays of the sun, lips are scarlet-red, like a shore with barns, and his radiant soul shines on everything around it like a moon".

The poetess compares the object of love to a giant choron (a traditional Yakut jar used for rituals). But this comparison is not based on the appearance of the object of admiration, but rather it is used to show its inner world: it is so deep and incomprehensible like the bottom of a large choron (a special Yakut vessel designated for ceremonial blessings). Not everyone is destined to "see" the bottom of the big choron filled with koumys (fermented mare's milk used for rituals). Likewise, not every woman is destined to learn the secrets of one's inner world. In Yakut poetry, and in the poems by A. Parnikova, the poetess usually compares the dishes with the poetical heroine herself (for example, this is often found in the poems by another Yakut poetess - O. Koryakina-Umsura). A. Parnikova is the exception in this case.

The personal traits of the lover are as unpleasant as a swamp in a dark forest. The lover is also endowed with supernatural powers. He can give the poetic heroine a fabulous life filled with intangible riches. It is not an extended comparison; it is a description of an abstract perfect character. The lover can breathe in real life into the lifeless camp of the lyrical heroine.

While in the ghazals of Central Asian poet Babur a great deal of attention is paid to the lover's external beauty by comparing different parts of her body with natural objects and phenomena (e.g., face and flowers, hair and the night, waist and slim trees), the ghazals of Sabarai Ilge, a description of the beauty of the man, the object of love, appear only once. In other cases, the poetess pays more attention to the description of the lover's attitude towards the lyrical heroine.

Let us now take one ghazal by A. ParnikovaSabaray Ilge as an example.

(Under the flaming clear cheeks of yours / How many times have I died, how many times have I been reborn? Under the gaze of your radiant eyes / Soaring up high, falling through the ground.../ On the lips of yours, similar to the valley covered with the sardana flower / Frozen to trembling bones, I sweated until the point of melting ! / As if I myself became both Christ and Icarus. / I fell ill with malaria from your fickle temper: / Don't let me get sick, don't overthrow me, Ilge - / Worship my loving heart!):

\section{Sagargalah khallanny kyyhar iyedestaring Annigar tohotoolon, hasta tilinnim?}

Sardangalah kunnuu sydyayar harakhtaryng Yohuger hallaannaan kotot, sirden timirdim...

Sardaanalaah kytylyy umayar uostary Yrduger of titirii tongot, uulla tirittim!

Bir Bayam Kiristies, emiye da Ikaar Buollum. Maardah maigygyttan syltaan titirirdethis:

Yaryy gynyma daa, suullaryma Ilgani, Танаra gyn kini taptyyr uyan surengin!

This ghazal by A. Sabara Ilge is written in the form of an appeal to the beloved one. The poetical subject refers to an object of admiration marked by the 2nd person, personal pronoun "you". Starting with the first half of the first three baits, we observe several basic traditional elements of the ghazals. At once, there is a clearly visible admiration of the lyrical subject and is expressed by the object of love with the help of the poetic figure of a tashbih-and mutlak (a direct comparison). Cheeks of the object of love are scarlet-red, like the morning dawn. Eyes shine like sunrays. And the lips are burning like a valley covered with bright sheds. Here, just like in the classical Turkic ghazal, the emphasis is made on the face of the object of love: by describing him, to do this, the poetess emphasizes his colour and roundness (comparison of objects by color and shape). In a classic ghazal, the face is usually compared to a rose, a tulip, or a rosehip. Thus, medieval poet Babur compares the eyes of the lover to the Chinese chamois, daffodils, cheeks with roses, tulips, and lips with rubies, corals, rosebuds, and red wine. In her ghazal, the Yakut poet refracts the traditional canonized images. The subject of the lip 
comparison is the flower that grows and is famous for its beauty in Yakutia.

The second semi-stitch of the first three baits is built on the repetition of rhetorical figures to convey the power of love experienced by the poetical heroine. There are also two poetic figures. It is literally the fis-si-fat or "exaggeration of quality" hyperbole, and tadad or "the opposite, antithesis, use of antonymous words: "dying - she was revived, "taking off - she failed to rise high up above), bound to the quake - she sweated as if she was in the middle of a meltdown". Another example is "Under the flaming clear cheeks of yours / How many times have I died, how many times have I been reborn?".

"olon - tilinnim" (she died - resurrected herself), "kotot - timirdim" (flying up high - she fell deep down), "titiriitongot-uullatirittim" (freezing to the bones - sweated until she was on the verge of melting). For example, "(Idestering) Annygartohotoolon, hastatilinnim?" _ "Under the cheeks of yours, which blush brightly red/ How many times have I died and how many times have I returned back to life?".

In the first half of the fourth bait, the poetical heroine compares herself to Christ and Icarus, which helps to prove the strength of her love. Due to unrequited love, the poetical heroine not only "died, was countlessly reborn", "flying high into the sky, fell through the ground", "frozen to the bones until she trembled, and melted!". But she also becomes a saint, just like the Christ, and possessed just like Icarus. Here both Christ and Icarus are represented by generalized images, being the ideal representations of humanity.

In the second half of the fourth bait, the poetical heroine reveals herself as a victim of the negative and menacing character of her lover. The character of her favorite image is compared to a swamp in a dark forest. In the final maqta, the lyrical subject asks her lover not to turn her into a sick person, not to bring her down to ruins, but to elevate her tender and loving heart to heaven.

The mentioned ghazal is structured based on the following motifs:

$1 \mathrm{~b} / 1 \mathrm{p}$. the beauty of the red cheeks of the beloved object

$1 \mathrm{~b} / 2 \mathrm{p}$. The motif of the poetical heroine's suffering from his cheeks

$2 b / 1 p$. the beauty of the shining eyes of the beloved person

$2 \mathrm{~b} / 2 \mathrm{p}$. The motif of the suffering of the poetical heroine from his gaze

$3 b / 1 p$. the beauty of the scarlet-red lips of the beloved one

$3 \mathrm{~b} / 2 \mathrm{p}$. The motif of the poetical heroine suffering because of his lips

$4 \mathrm{~b} / 1 \mathrm{p}$. The motif of comparing herself to Christ and Icarus
$4 \mathrm{~b} / 2 \mathrm{p}$. motif of the poetical heroine's disease due to the ugly character of the lover

$5 b / 1 p$. The motif of the poetical heroine's cry for pity

$5 b / 2 p$. The motif of the poetical heroine's request to the lover to elevate her love.

The definition of motifs in this ghazal indicates that the state of the poetical heroine is specified here. They (motifs) are mostly grouped around the first semantic center.

As noted above, I. Stebleva sees a close relationship between the baits. According to her, if you remove at least one bait, one half-stitch, the ghazal loses its meaning. Or if you move the bait poems around, the poetic work loses its artistic integrity. In the ghazal, the composition is constructed sequentially and linearly, since it occurs together with the movement of the author's thoughts. Let us consider this as an example of this ghazal of the Yakut poetess. During the first three baits, the expansion of meaning in the ghazal is gradually increased, culminating in the fourth bait. The fourth bait contains an explanatory statement linking the two characters, because it is from this passage we learn that the cause of the lyrical heroine's suffering is precisely unrequited love and the ugly character of the beloved one. The lyrical heroine is so in love that for the sake of his affection, she is willing to do anything, even be as almighty as Christ and Icarus, and yet she feels sick because of this hopeless position. In conclusion, in the ghazal (fifth bait) presented in the final passage there is a cry of the lyrical heroine, literally "a cry of the soul". The lyrical heroine begs her beloved one not to destroy her, but instead to elevate her, Ilge, with love.

\section{Conclusion}

Thus, considering the ghazals of Yakut poet A. Sabara Ilge, we can draw the following conclusions. The ghazals of Anna Parnikova are dedicated to the image of love and love experiences of the lyrical heroine, which is a characteristic feature of such a genre as the ghazal. The poetess adheres to the compositional features of the genre and the principles of addition of its figurative system. Also in the final maqta bait of each ghazal of the poetess, there is a tahallus or the poetic name of the author. A. Parnikova does not follow only one formal side: she does not follow the rhythmic structure of the halfstitch of the first bait, which is a sign of the beginning of the ghazal in this poetic work of art.

In general, apart from the last comment, the ghazals of young poet A. Parnikova-Sabarai Ilge are an example of the reconstruction of the structuralmeaningful, compositional-strophic feature of the Eastern-Asian poetic genre on the Yakut land.

Since poets should strictly follow not only the structure of the genre, but also the figurative system 
in ghazals, both Eastern and Yakut poets, in our opinion, have come across many difficulties. In the canonized system of ghazals, eyelashes or eyebrows are compared with shoots of onions, the lips of the beloved one - with rubies, cheeks - with a tulip, mole on the face - with bead, hair, curls - with violets, etc. In general, most comparisons are intended to describe beauty and to emphasize the femininity of the girl or the woman. Perhaps, this is the reason why the ghazals of the poetess are not distinguished by the developed colorfulness, as those ghazals of the male poets.

Thus, while Yakut poets of the previous decades roughly imitated the European and Eastern genre forms, recently the tendency has been to precisely follow their traditions, not only in terms of structure, but also in terms of the content.

In this article, we considered the works that have defined the main trends of the genre and the search for them among modern Yakut poets, who make a significant contribution to the development of literature of the peoples of the Russian Federation.

\section{References}

1. N.N. Toburokov, Yakutsky stikh (Yakut Poetry) (Yakutsk: Yakut Book Press, 1985)

2. I.V. Stebleva, Semantics of Babur's ghazals (Moscow: Science Press, 1982)

3. S.N. Ivanov, The Scroll of the Centuries. Turkic classical poetry of the 15-20th centuries (Leningrad: LGU Press, 1991)

4. S.N. Ivanov, Five centuries of the Uzbek ghazals from In the imperishable beauty it appears. Uzbek classical poetry of the 15-20th centuries (Moscow: Nauka, 1977)

5. I.V. Stebleva, Essays of Turkish mythology: based on fairy tale (Moscow: Vostochnaya literatura, 2002) 